Journal of Primary Education
$9(5)(2020): 493-500$
UNNES
https://journal.unnes.ac.id/sju/index.php/jpe

\title{
The Effectiveness of Zondag Mandaag's Game on the Improvement of Basic Movement and Early Childhood Character
}

\author{
Sri Pujiati ${ }^{1 凶}$, Kustiono Kustiono $^{2}$ \\ DOI: https://doi.org/ 10.15294/jpe.v9i5.43056 \\ ${ }^{1 .}$ RA Al Amin Banyumanik Semarang, Indonesia \\ 2. Pascasarjana, Universitas Negeri Semarang, Indonesia
}

\begin{tabular}{l} 
Article Info \\
\hline History Articles \\
Received: \\
9 Sebtember 2020 \\
Accepted: \\
11 October 2020 \\
Published: \\
31 December 2020 \\
\hline Keywords: \\
Basic movement, \\
Character,Zondag \\
Mandaag \\
\hline
\end{tabular}

\begin{abstract}
The lack of learning that stimulates basic movements and early childhood character. This is due to several things including the teacher's lack of understanding about the classification of basic movements and the environment that is less supportive. This study aimed to analyze the effectiveness of Zondag Mandaag game on improving basic movements and early childhood character. The experimental design that was carried out in this study was the True Experimental in the form of a Pretest-Posttest Control Group Design to analyze quantitative data on the effectiveness of the Zondag Mandaag game on improving basic movements and early childhood character. The result shows that there is an increase in basic movements and characters of early childhood after treatment with Zondag Mandaag games. It is evidenced by the average results of the first test is 58.83 in the experimental class and 58 in the control class, while the average score of the final test for the experimental class is 75.5 and 63.83 for the control class which shows an increase of 16.67 in experimental class and 5.85 in the control class. Thus, it can be concluded that the Zondag Mandaag's game is effective in improving the basic movements and character of early childhood.
\end{abstract}

\footnotetext{
$\bowtie$ Correspondence address:

J1 Kyai Mojo I Rt.04 / V Srondol Kulon Banyumanik Semarang.

E-mail: sripujiatiasyrofi@gmail.com

p-ISSN 2252-6404

e-ISSN 2502-4515
} 


\section{INTRODUCTION}

A perfect life is the main purpose for human being, but human nature only God determines. This is evident sometimes we find the children who develop not following their age, either too late or too fast from their age. Even so, they still get protection and freedom in studying. Ki Hajar Dewantoro argued, "Education generally means the effort to advance character (character, inner strength), mind (intelligence) and physicality of children in harmony with nature and society" (Raharjo, 2014).

Considering that education is an important asset for the development of a country, it is stated in article 3 of Law Number 20 of 2003 concerning the National Education System, it is stated that "National Education has the functions to develop and shape the character and civilization to educate the life of the nation, aiming at developing the potential of students so that be a human being who believes and is obedient to God Almighty, have a noble character, healthy, knowledgeable, capable, creative and become democratic and responsible citizens.

Learning is an activity in which teachers do certain roles so that students can learn to achieve the expected educational goals (Mulyasa, 2015). The teacher is one of the determining factors for the success of the teaching and learning process in education, so the teacher is required to understand and be able to have pedagogical competence so that the teacher can carry out the learning process well. Teachers as facilitators of children's ability development must also be responsive to children's physical motor development. Physical motor development of children must be adapted to the child's developmental age. Education is said to be good and must fulfill the minimum standards in the learning process, related to how the learning system, models, and preparation that are used in it for cognitive, affective, and psychomotor development to develop in a balanced manner.
This is under the opinion of Lickona, (2012) that character does not function in a vacuum, it functions in a social environment. Likewise stated by Mulyasa, (2018) that character education has the aim of improving the quality of educational processes and outcomes that lead to the formation and noble morals of students as a whole, integrated, and balanced according to the competency standards of educational unit graduates. Similar research from Pranoto (2015) states that traditional Javanese games that are integrated through learning will be able to become an alternative innovative learning method for developing good character in early childhood students. The role of parents and the community is expected to be able to socialize character-building programs through traditional games that are developed in schools and the community.

According to the Ministry of Education and Culture (2010), the cultural values and character of the nation consist of 18 cultural values and characters which include: religion, honest, tolerance, discipline, hard work, creativity, independence, democratic, curiosity, national spirit, love for the country, respect for achievement, friendly/communicative, peaceloving, reading, environmental care, social care, and responsibility.

In Indonesia, which is rich in traditional games and games that are integrated with learning instruments, teachers should be able to take advantage of this wealth as a means of fun learning models. Given that early childhood tends to like playing, both directly and indirectly. Early childhood motoric physical activities can be carried out with the principles of Fun and Enjoy, or happy and relaxed, of course, adjusted to the physical abilities of each child. Like the Zondag Mandaag game. The Zondag Mandaag game is one of the games which are played by Indonesian children since the Dutch colonial era. In the research journal Rahmawati et al. (2018) explain that: Zondag Mandaag itself is from Dutch, each of which has the means Zondag is Sunday, Mandaag is Monday with a predetermined concept of how to play. Usually, this game is played by the girls. 
In Central Java, it is called Sundanese Manda or engklek. At this time, it is rarely played by children. Wulandari's research (2015) also explained that children's social competence can be developed based on five aspects, namely: selfconcept, responsibility, emotional expression, social interaction, and problem-solving abilities. These aspects can be found in traditional games, such as the gobak shodor game in which children can interact socially (teamwork), express emotions (anger, sadness, and joy), responsibility (uphold the rules that have been made together), self-concept (know what is good and bad, if you doing a cheat you will be shunned by your friends), problem-solving abilities (situations and conditions when playing encourage children to make decisions).

The lack of schools in learning that stimulates basic movements is due to several things, including the teacher's lack of understanding of the classification of basic movements and the less supportive environment. There are still some students who do not like playing activities because they are tired. Although the learning process in early childhood should be carried out through learning while playing or playing while learning. Less traditional games to be used in learning, especially Zondag Mandaag. Teachers do not understand gross motoric skills included in the basic movement. Parents' concern for children's character development is neglected. Lack of children's interaction with the home and school environment. Teachers are less creative in creating a game. How big is the character development of early childhood?

Based on these problems, this study is conducted to analyze the effectiveness of the Zondag Mandaag game on the basic movement skills and character of children aged 5-6 years.

\section{METHOD}

The experimental design carried out in this study was the true experimental design in the form of a pretest-posttest control group design which was an experiment in which the researcher can control all external variables that affect the course of the experiment. The characteristic of true experimental design was that the sample used as an experiment and the control group was taken randomly from a certain population.

The technique of taking subjects or data sources was carried out by purposive sampling, which was a method or technique for sampling data sources with certain considerations (Sugiyono, 2016). The location of the institution was in Banyumanik District, The institution was under the auspices of the Ministry of Religion, has the same curriculum, has teachers who already have a $70 \%$ S1 diploma, as well as an adequate number of students for research sites.

From the eight institutions in the Banyumanik sub-district, there were only two institutions that fulfill the above criteria. These institutions were RA Nawira Aulia and RA Aisyah which were subsequently designated as locations and research subjects, RA Aisyah as the experimental group, and RA Nawira Aulia as the control group. The number of each group were 30 students.

Quantitative data to assess the improvement of basic movements and early childhood character were collected by observation, documentation, and interviews as data collectors. Observations were made by observing children's activities directly and seeing videos made by parents. Interviews were conducted to deepen the results of the observations which were made. Quantitative data analysis included the validity test, reliability test, normality test, homogeneity test. Final data analysis included $\mathrm{t}$-test and $\mathrm{N}$-gain test to determine classical completeness, average difference, and increase in the average value of pretest and posttest. The shape of Zondag Mandaag game is. as shown in Figure 1.

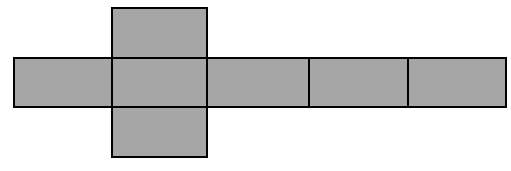

Figure1. The shape of Zondag Mandaag

The basic movements stimulated through the Zondag Mandaag game include walking, 
jumping, landing, cranking, running, bending, turning, pulling, pushing, and throwing. The character of children that can be stimulated through the Zondag Mandaag game include honesty, discipline, hard work, independence, democracy, love for the country, creative, and responsible.

\section{RESULTS AND DISCUSSION}

The average pretest results of the control group and the experimental group of basic movement and early childhood characters were in a low category. As shown in Table 1 below.

Table 1. The Results of Average Pretest Basic Movement and Early Childhood Character

\begin{tabular}{lll}
\hline Group & $\begin{array}{l}\text { Average } \\
\text { Basic } \\
\text { Movement }\end{array}$ & Character \\
\hline Experiment & 58.83 & 55.33 \\
Control & 58.00 & 54.50 \\
\hline
\end{tabular}

Table 1 shows the results before the experimental group and the control group is given treatment with the Zondag Mandaag game treatment. Because the use of parametric inferential statistics requires that the data to be analyzed must be normally distributed. The results of the pretest and posttest normality tests are presented in Table 2 and Table 3.

Table 2. Pretest and Posttest Normality Test of Basic Movement Tests

One-Sample Kolmogorov-Smirnov Test

\begin{tabular}{lllll}
\hline \multicolumn{4}{c}{ Basic Movement } & \\
& $\begin{array}{c}\text { Experiment } \\
\text { Pretest }\end{array}$ & Posttest & Control \\
& Pretest & Posttest \\
\hline $\mathrm{N}$ & 30 & 30 & 30 & 30
\end{tabular}

Asymp. Sig. (2-

$\begin{array}{lllll}\text { tailed) } & .122 & .203 & .193 & .475\end{array}$

a. Test distribution is Normal.
Table 3. Pretest and Posttest Normality Test for Early Childhood Character

One-Sample Kolmogorov-Smirnov Test

Early Childhood Character Experiment Control

\begin{tabular}{ccccc} 
& Pretest & Posttest & Pretest & Posttest \\
\hline $\mathrm{N}$ & 30 & 30 & 30 & 30 \\
$\begin{array}{c}\text { Asymp. } \\
\begin{array}{c}\text { Sig. (2- } \\
\text { tailed) }\end{array}\end{array}$ & .181 & .058 & .394 & .572 \\
\hline
\end{tabular}

The hypothesis for the normality test is HO if the initial ability data is normally distributed and $\mathrm{H} 1$ if the initial ability data is not normally distributed. The test criteria are if the significance value $>0.05(\alpha)$ then $\mathrm{H} 0$ is accepted. From t Tables 2 and 3 all data were normally distributed.

The validity test was carried out to test the level of validity and the extent to which a measuring instrument can be trusted or reliable. It can be stated that a question item is said to be valid if it has a value of rcount $>$ rtable, namely 0.05 .

The results show that the average rcount value of the questionnaire is 0.778 to 0.808 . This is because rcount $>.05$ with a significance level of $5 \%$ and $\mathrm{N}=30$. Based on the measuring instrument for basic movement abilities and early childhood character in the Zondag Mandaag game it was officially stated that the instrument was valid.

The homogeneity test is carried out to determine whether the control and experimental groups have the same ability (homogeneous) or not. The test criteria are that the data is said to be homogeneous if the value of Fcount ( $F$ levene statistic) < Ftable and the significance value is greater than $\sigma$ with $\sigma=0.05$. The results of the homogeneity test is presented in Table 4 .

In Table 4 it is known that based on the Test of Homogeneity of Variances table, a pretest significance value of 0.590 and a posttest significance of 0.544 for basic movement is obtained and a pretest significance value of 0.908 and a posttest significance value of 0.523 for early childhood characters was obtained. Because $0.590>0.05$ and $0.544>0.05$ and 
$0.908>0.05$ and $0.523>0.05$, it can be the control and experimental groups have the concluded that the pretest and posttest data for same variance (homogeneous).

Table 4. The Results of Homogeneity Test Pretest and posttest values.

Test of Homogeneity of Variance

\begin{tabular}{|c|c|c|c|c|c|}
\hline Pre-Test & & $\begin{array}{l}\text { Levene } \\
\text { Statistic }\end{array}$ & df1 & $\mathrm{df} 2$ & Sig. \\
\hline Basic Movement & Based on Mean & .293 & 1 & 58 & .590 \\
\hline $\begin{array}{l}\text { Early Childhood } \\
\text { Character }\end{array}$ & Based on Mean & .013 & 1 & 58 & .908 \\
\hline \multicolumn{6}{|l|}{ Posttest. } \\
\hline Basic Movement & Based on trimmed mean & .373 & 1 & 58 & .544 \\
\hline $\begin{array}{ll}\text { Early } & \text { Childhood } \\
\text { Character } & \\
\end{array}$ & Based on trimmed mean & .412 & 1 & 58 & .523 \\
\hline
\end{tabular}

The paired sample T-Test is carried out to determine the increase in basic movement and the improvement of early childhood characters from basic movement instruments and early childhood characters in the Zondag Mandaag game with the following results.

The result of the Paired Sample T-Test shows that for the category of pre-test values for basic movement experimental instruments and post-test values for basic movement experimental instruments, the significance is (Sig $=0.00<\alpha=0.05$ ). Since the value of tcount $>$ ttable $(27.577>1.697)$. It can be concluded that $\mathrm{Ha}$ is accepted, and Ho is rejected. This shows that there is an influence between the pre-test value of the basic movement experimental instrument and the post-test value of the basic movement experimental instrument.

The results of the paired sample t-test show that for the category of pre-test value for early childhood character experiments and posttest for early childhood character experiments, the significance value ( $\mathrm{Sig}=0.000<\alpha=0.05$ ). Because the value of tcount $>$ ttable $(21.400>$ 1.697). This shows that there is an influence between the results of the pre-test experiment and the post-test of the early childhood character experiment.

The improvement test is carried out to know how much the increase in the average basic movement and character of early childhood. It can be seen in Table 5 .

Table 5. The Results of Basic Movement NGain

\begin{tabular}{lll}
\hline Criteria & Interval & Frequency \\
\hline Low & $\mathrm{g} \leq 0.3$ & 0 \\
Moderate & $0.3<\mathrm{g} \leq 0.7$ & 30 \\
High & $0.7<\mathrm{g}$ & 0 \\
\hline Average gain & 0.42 & \\
\hline
\end{tabular}

Table 5 shows that of the 30 students who do the treatment, no children experienced a low increase, 30 children experienced a moderate increase, and no children experienced a high increase. The average gain or the increase in pretest and posttest results reach 0.42 in the moderate category. These data indicate that learning through the Zondag Mandaag game affects increasing basic movement. It can be seen in Table 6.

Table 6. Early Childhood Character N-Gain Results

\begin{tabular}{lll}
\hline Criteria & Interval & Frequency \\
\hline Low & $\mathrm{g} \leq 0.3$ & 0 \\
Moderate & $0.3<\mathrm{g} \leq 0.7$ & 30 \\
High & $0.7<\mathrm{g}$ & 0 \\
\hline Average gain & 0.36 & \\
\hline
\end{tabular}


Table 6 shows that of the 30 students who do treatment, no child experienced a low increase, 30 children experienced a moderate increase, and 0 children experienced a high increase. The average gain or increase in pretest and posttest results reach 0.36 in the low category. These data indicate that learning through the Zondag Mandaag game affects improving the character abilities of early childhood even though on a moderate scale.

According to research conducted by Ilham et al. (2016), it is explained that traditional games are suitable for training and as a medium for learning sports because they can form the skills, speed, strength, agility, and so on if it is done well. Furthermore, similar research is written by Yuliana, Chairilsyah, and Hukmi (2016) show that there is a difference in the form of an increase in children's gross motor skills before and after the treatment of traditional boiboian games on gross motor skills of children aged 4-5 years at Early childhood education Mitra Handayani Pekanbaru.

Based on research conducted by Efendi (2015) in traditional games carried out at RA Khoiriyatus Sibyan which can stimulate early childhood development with the observations of researchers, there are several unique things including traditional games carried out following the sequence of children's sensory development and the child's development process which is adapted to the age and the application of traditional games that involve physical motor skills of children.

Related to character research, there are also several studies conducted to compare the Zondag Mandaag game with other media to improve early childhood character. Nur (2015) in her research based on this literature study compares the impact of modern games which affect the characters that will be awakened in children. This study also compares modern games with traditional games on children's character building. The results of this study restore traditional children's games as children's games which can currently be an alternative to create a generation of superior characters and avoid addiction to modern games on mobile phones or similar electronic games.

Similar research written by Rahayuningsih \& Sholikhan (2016) shows that the planning, implementation, and evaluation of disciplinary character building in Islamic AsSalam Elementary School have been well conceptualized. The method that is used by teachers in disciplinary character education is effective and encourages students to make better character changes.

\section{CONCLUSION}

The conclusions of this study are there is the effectiveness of the Zondag Mandaag game to improve the basic movement, there is also the effectiveness of the Zondag Mandaag game to increase character in early childhood. Thus the Zondag Mandaag game can be refined as a medium of learning in improving early childhood character, including honesty, tolerance, discipline, hard work, creativity, independence, democracy, curiosity, national spirit, love of the country, respect for achievement, friendly/communicative, love of peace, care about the environment, care about social and responsibility. And can stimulate basic movement such as leaping, engklek, throwing, swinging, bending, and turning. The zondag mandaag game is more suitable for early childhood, considering that this game is played with a small group and the risk of accidents that occur is very small, the supervision is simple and it can be done with older people.

\section{REFERENCES}

Anggraini,M.A., Karyanto, Y., \& AS, W. K. (2018). Pengaruh Permainan Tradisional Lompat Tali Terhadap Perkembangan Motorik Kasar Anak Usia 5-6 Tahun. Journal of Early Childhood Care and Education, 1(1), 18-25.

Aypay, A. (2016). Investigating The Role of Traditional Children's Games in Teaching Ten Universal Values in 
Turkey. Eurasian Journal of Educational Research, 62(62), 283-300.

Charles, A. G., Abdullah, M. R., \& Musa, R. M. (2017). The Effect of Traditional Games Intervention Programme in the Enhancement School- Age Children's Motor Skills: a Preliminary Study. Movement, Health \& Exercise, 6 (2), 157-69.

Ekayati, S.A.I. (2015). Pengaruh Permainan Tradisional "Gobag Sodor" Terhadap Kecerdasan Intrapersonal dan Interpersonal Pada Anak Usia Dini. Didaktika, 13(3), 1-10.

Erfayliana, Y. (2017). Aktivitas Bermain dan Perkembangan Jasmani Anak. Terampil: Jurnal Pendidikan dan Pembelajaran Dasar, 3(1), 145-158.

Erdiana, 1. (2016). Pengaruh Permainan Tradisional Gobak Sodor Terhadap Perkembangan Motorik Kasar dan Sikap Kooperatif Anak TK Kelompok B di Kecamatan Sidoarjo. Jurnal Pedagogi, 2(3), 9-17.

Fajriah, N. (2017). Pengaruh Penggunaan Permainan Tradisional Gundu. EDumath: Jurnal Pendidikan Matematika,3(1),42-48.

Febrialismanto. (2017). Gambaran Motorik Kasar Anak Usia 4-5 Tahun di Taman Kanak-Kanak Kecamatan Bangkinang Kabupaten Kampar Propinsi Riau. Jurnal Pesona Dasar, 5(2), 1-14.

Febriani, E. (2016). Upaya Meningkatkan Pengembangan Motorik Kasar (Melompat) Anak Melalui Permainan Lompat Tali pada Kelompok B TK A1Hidayah Palaosan Tahun Pelajaran 20152016. Prosiding Ilmu Pendidi kan, 1(2), 35 40.

Hanief, Y. N,. \& Sugito. (2015). Membentuk Gerak Dasar pada Siswa Sekolah Dasar Melalui Permainan Ttradisional. Jurnal sportif, 1(1), 60-73.

Hayati, Mynarwati CH, \& M. A. (2017). Effect of Traditional Games, Learning Motivation and Learning Style on Childhoods Gross Motor Skills.
International Journal of Education and Research, 5(7), 53-66.

Ilham, A., M. Syaputra, E., \& Munar, H. (2016). Pemanfaatan Permainan Tradisional dalam Pencapaian Indikator Pembelajaran. Jurnal Pengabdian Pada Masyarakat, 5(2), 22-29.

Indriati, R. \& Warsini. (2016). Pengaruh Permainan Edukatif Terhadap Perkembangan pada Anak di PAUD Cinta Bunda Desa Baran Sukoharjo (The Influence of The Game Edukatif Against The Development of The Children in Early Childhood Education Cinta Bunda Village Baran Sukoharjo). IJMSIndonesian Journal on Medical Science, 3(1), 115-121.

Iswantiningtyas, V., \& Wijaya, I. P. (2015). Meningkatkan Kemampuan Motorik Kasar Anak Usia Dini Melalui Permainan Tradisional Gobak Sodor. Jurnal PINUS, 1(3), 249-251.

Julianti, R. R., \& Alawiyah, T. (2016). Pengaruh Permainan Kecil Terhadap Motor Educability. Jurnal Ilmiah PENJAS, 2(2), 77-87.

Kemdikbud. (2016). Peraturan Menteri Pendidikan dan Kebudayaan Republik Indonesia Nomor 22.Tahun 2016 Tentang Standar Proses Pendidikan Dasar dan Menengah. Climate Change 2013 - The Physical Science Basis, 1-30.

Komputerisna, A. A., \& Diana, D. (2016). Gross Motor Skills of The Children's Group A Judging from Demonstration Method of Motion and Song in Kindergarten Pertiwi Nusa Indah. BELIA: Early Childhood Education Papers, 5(1), 7277

Riska, C. S., \& Satria, B. (2016). Alat Permainan Edukatif dengan Perkembangan Motorik Anak Usia Prasekolah di Pemukiman Lamlheu. Jurnal Ilmiah Maha siswa Fakultas Keperawatan, 1(1), 1-6

Riyanto, I. A., \& Kristiyanto, A. K. (2017). Pengembangan Model Pembelajaran Keterampilan Motorik Berbasis 
Permainan Untuk Anak Sekolah Dasar Usia 9-10 Tahun. TEGAR: Journal of Teaching Physical Education in Elementary School, 1(1), 94-110.

Rochmani, I. U. (2016). Permainan Tradisional Engklek Berpengaruh Terhadap Perkembangan Motorik Anak. Jurnal Pendidikan Usia Dini, 8,1-11.

Salamah, S., \& Miftahillah, M. (2018). Pengaruh Permainan Tradisional Engklek terhadap Perkembangan Fisik Motorik Kasar Anak Usia Dini Usia 4-5 Tahun di TK Ar-Rieza Dua Beji Pasuruan. In PROCEEDING: The 3rd Annual International Conference on Islamic Education, 3(2), 165-177.

Setiawan, M. H. Y. (2016). Melatih Keterampilan Sosial Anak Usia Dini Melalui Permainan Tradisional. Jurnal Dimensi Pendidikan dan Pembelajaran, 5, 29-37.

Vanagosi, K. D. (2016). Konsep Gerak Dasar untuk Anak Usia Dini. Jurnal Pendidikan Kesehatan Rrekreasi, 1(1), 72-79.
Wati, S. E., \& Aizah, S. (2016). Pengaruh Pendidikan PAUD Terhadap Tingkat Perkembangan Anak Usia Toodler di PAUD Diponegoro Desa Pucanganom ds. Sukorejo Kec.Gurah Kab. Kediri. Jurnal Ilmu Kesehatan, 5(1), 128132.

Yuliyani, S. K., Hartanti, Y. S., Halimah, M., \& Apriyanti, M. (2017). Pelaksanaan Asesmen Kemampuan Motorik pada Anak dengan Hambatan Motorik di Taman Kanak-Kanak. International Conference, 367-374.

Yusmawiari, Suarni,N. K., M. M. (2017). Pengaruh Metode Bermain Aktif terhadap Kemampuan Gerak Lokomotor Anak Kelompok A PAUD Pelita Kasih Singaraja. e-Journal Pendidikan Anak Usia Dini , 5(2), 199-209. 